\title{
Tarantism: The Italian Pizzica from Music Therapy to New Formsof Performance
}

\author{
Daniele Zappatore
}

La Sapienza University, Rome

\begin{abstract}
Far from being a mere historical reconstruction of the complex and culturally conditioned zymology of tarantism, the aim of this paper is to highlight its dynamic diachronically. Originally came from Italy, tarantism and its dynamics couldn't be disjoined from its ancient concepts: cults, ritual possession, choral-music exorcism, that can be understood as a music therapy. In ethnomusicology standpoints, the particular significance would join the analysis of its from and its cultural aspect to elaborate the preservation of its choral nature or even its original ritual use in some maintained tarantellas. Through a cultural approach, this paper showed how, in the next period, political and economic development of these processes of capitalization resulting form of commodification focused in the aspects of dance and music. This lead to a decontextualization of the tarantula's symbol into ideological discourse that transformed into cultural heritage in order to give it the status of capital goods, to be launched in cultural market.
\end{abstract}

Keywords: tarantism, diachronic dynamic, cultural capital

\section{INTRODUCTION}

Far from being a mere historical reconstruction of the complex and culturally conditioned symbology of tarantism, the aim of this paper will be to highlight, in a diachronic perspective, the dynamism of a ancient historical-religious phenomenon, out over the centuries before being rediscovered and recovered through forms of spectacolarization in line with the global politics of the contemporary world. Tarantism was a 'minor' religious formation widespread in southern Italy (especially in Puglia) predominantly among peasants that revolved around the mythical-ritual horizon of a spider (the tarantula) that bites and poisons. This 'evil' was cured with a choral-musical exorcism connected with the symbolism of various colors and with the repetition of seasonal crisis in conjunction with the era of the awakening spring and the harvest of summer fruits.

Regarding the origins of tarantism is useful to consider its classical antecedents: Apulia belonged to the cultural area of Magna Grecia and there are significant points of contact between the ideological system of tarantism and greek theories on musical catharsis, in 
the framework of orgiastic and initiation cults (Di Mitri, 1996); on the other hand tarantism is framed within a very wide class of phenomena generally classified as 'ecstatic cults ' or forms of 'ritual possession'. From this point of view there are many ethnographic parallels to consider, from the african cults, to those Sardinian and Liberian: kinship construed as side order of relations within which tarantism kept its own geographical and symbolic individuality, and yet leaves to glimpse a common cultural protomediterranean home of the whole family (De Martino, 1966).

But tarantism must be assessed mainly as an episode inside the medieval process of expansion of the Christian society, engaged in a bitter polemic against the orgiastic cults. Tarantism entered in various relationship with its hegemonic forms of cultural life, in particular by binding with the natural magic; the intro music of the Baroque age marked the top of its cultural circulation. But when Neapolitan Illuminism dissolved the myth of the tarantula, tarantism entered in crisis and then began its decline. On another level, and with more direct disruptive influence, Catholicism worked attempt to reabsorb tarantism under the miraculous cures in the chapel of St. Paul in Galatina: here the traditional form of the rite met increasing difficulties of implementation. It was thus taking the final step: once disjointed the connection between crisis and choral-musical exorcism, once the symbol of tarantula came into open conflict with all hegemonic forms of cultural life - and the values that they expressed -, tarantism started to withdraw in disease: its cultural defenses were dismantled and rendered inoperative, revealing their relentless conflict with the movement of modern civilization.

The whole historic orbit of tarantism appears linked to important and decisive moments of the story of western civilization. There's no doubt that the cult has always impressed in cultural memory: the constant interest towards the subject is evidenced by its wealth in the diachronic literature. Even today tarantism can advance its modest titles (please refer to the wide tarantistic bibliography - still in progress - Tela infinita, edited by Gabriele Mina and Sergio Torsello, 2006), but as a result of the research of Ernesto De Martino each reflection moves to greater critical awareness: if too often biomedical research in the past has brought the phenomenon to aracnidism or to mental disorders (Di Mitri, 2006), today we know that tarantism was not a disease, but a symbolic form that gave order to a social, psychological, existential, economic and historical disorder. Phenomenon that even today stimulates the interest of scholars and become a topic of lively debate that concerns us.

In research on this topic ethnomusicology has always had particular significance, since the cult was manifested in its decisive and therapeutic phase as ritual choral-musical drama, grafted on the myth of the tarantula. Hence the need to analyze, both in terms of ethnographic exploration and of diachronic documentation, the choral-musical forms (as 
technical protection from the crisis - in a magical - religious framework - through traditionalized models of gestures, sounds, shapes, rhythms and melodies; as instruments of evocation and control of the crisis, operating and socially accepted) and the music therapy of tarantism. Crisis, rhythm, melody, mimicry and therapeutic resolution were in tarantism in organic connection, like a drama that from an initial laceration gain its own dissolution (Carpitella, 1966).

Regarding the dance involved intarantism, the oldest literature refers only occasional and quick hints on this topic. During the ethnographic exploration of 1959 Diego Carpitella identified a bipartite choral cycle, indefinitely repeated during the rite until the time of 'healing': this cycle was divided into two phases, the first on the ground, which mainly deals with the identification with the mythical animal, and the second standing, mainly oriented towards an agonistic resolution of the possession, through proper dancing figures. The 'pizziche tarantate' constituted the kind of rhythm and melody normally used in the music therapy of tarantism, although the oldest documents emphasized the occasional use, within the healing process, of melancholy songs, or even funeral dirges. This music can be traced back to the 'tarantella' diffused in the geographical spread ranging from southern Lazio to Sicily, which present some homogeneous characters, especially as regards meter-rhythmic systems, generally iterative with micro-variation, that support them (this type of structure has many features in common with the music of African matrix and with jazz, especially with regard to the particular way of conceiving and organizing rhythm. The explanation of such rhythmic affinities has to be found in geographic proximity and in historical and social connections between the peninsular and insular italian south and other cultures of the Mediterranean basin). Particularly in the south, where the tarantella maintained - until a few decades ago - its function - occasion, this music has preserved its choral nature and sometimes even its original ritual use. From the point of view of rhythm, then, the different types of tarantella and pizzica have some common characteristics:

1. an always-detectable pulsation, both if expressed or implied;

2. an ambiguous rhythmic structure based on a mixture of binary and ternary figurations, in which the displacements of accents have a fundamental dynamic role;

3. a conflict between metric units and rhythmic figures;

4. a pyramidal architecture of the rhythmic figures distributed between the percussion instruments (Central instrument in the rhythmic section is the tambourine, $<<$ perfect symbolic expression of the presence of complementary opposites (the treble of the rattles and the bass of the skin) reconciled and reduced to unity from the magic-ritual circle of the frame. More precisely, it is the tool of what allows the union of heaven and earth, the sacrifice, and is built with goatskin, sacrificial animal 
par excellence. Custodians from Salento manifested towards it a special love and dedication and still talk about it today with emotion. >> (De Giorgi, 1999)

There are strong reasons to believe that these characteristics have their basis in the ritual function of the music to which they belong (Giannattasio, 1991). The most significant case in this sense is precisely that of pizziche tarantate in Puglia, widely studied by Carpitella, in which music accompanies the dance of the 'tarantato' and helps to induce the trance. Carpitella finds in this music a $<<$ clear division between the beat of the rhythmic section (accordion, guitar and tambourine) and the offbeat of the violin that occurs mainly through syncopated and repeated notes $>>$. Speaking of this dichotomy between beat and off beat, he adds: << resulting two aspects of this music, that should be thoroughly analyzed from a psychological standpoint, as they are reflected in two typical moments of the religious technologies: expansion and aggravation of the crisis that musically resolves in particular expressive techniques (accentuative rhythmic, syncope, instrumental effects, ways of percussion of the tambourine, cries, lamentations rhythm); and control of the crisis that reflected mainly on the isometric rhythm >> (Carpitella, 1966).

The continuous temporal 'shift' caused by the change of the accents in relation to the rigid isochronism of the pulsation, and the motor conditioning that this rhythmic conflict induces in the movements of the dance, could therefore be considered as functional factors (although not necessarily the only determinants) for the unleashing of ritual trance (in describing the choral-musical practice of tarantism Tullio Seppili, president of the Italian Society of Medical Anthropology, refers to the particular idea of harmony typical of many medical cultures such as Oriental, African, and also Greek. The trance of 'tarantati' should be attributed in his opinion to a form of bioenergetic therapy: the stress of the body operates a deconstruction of the psycho-physical equilibrium and is then harmonized through a particular iatromusic with a vortexlike and persistent rhythm). It is not a coincidence that in the rhythms of the pizzica and tarantella performed by modern folk groups, now dropped from the traditional ritual uses, ambiguity and meter-rhythmic conflicts are very attenuated, or even none at all. Besides already Carpitella could see that the conditions of wear and dislocation besetting Salento's tarantism had impoverished the tarantella practiced in the past:compared with diachronic attestation, infact, the elective nature of 'tarantati' for particular melodies was disappearing, and the instrumental ensemble appeared significantly reduced compared to the wide range of instruments used in the past.

In the last decades of the twentieth century tarantism in forms designed by De Martino went disappearing. But in its place, with the start of the new mediatic millennium, a powerful machine of cultural patrimonialization has made his way, affecting also the 
memory of the founder of Italian anthropology. The land of remorse (the land of remorse is also the title of the English translation - made by D. L. Zinn (2005) - of the famous study published by de Martino after the ethnographic research of 1959) seemed to have become the land of an intellectual and political-economic conflict on intangible cultural heritage. This happened in the wake of a rapprochement between processes of patrimonialization and commercialization: a cultural marketing involving different levels of knowledge and various social agents (Pizza, 2004). To observe tarantism today means coming to terms with the complex plot of various practices of writing, art, cinema, philosophical meditation, academic anthropology and cultural politics put in place by local institutions. However, political and economic development of these processes of capitalization and the resulting forms of commodification have focused on the aspects of music and dance.

Today, therefore, the local social agents use scientific-academic knowledge to reread tarantism and to legitimize a process of remembrance, not so much of the therapeutic ritual or cult of possession connected with social suffering, rather of its dancing and musical aspects: tarantism becomes above all folk music and dance. Local, national and international artists are rediscovering the aesthetic values of tarantism, participating in are shaping of the past that is a sort of reversal of the the tradition: decontextualizing the symbol of the tarantula and inputting it in an ideological discourse about rebirth, it was first transformed into acultural heritage - and therefore, in a stretch of identity to be reassessed-in order to give it the status of capital goods, to be launched on the global cultural market (Steven Feld drew about this topic the concept of 'Schizophonia', which tends to reflect a contrast between music as expression and music as commodity, and therefore reveals itself as a useful notion to explore the dynamics of the world music traffic in reference to the processes of acquisition of power and market of the multinationals music industries, which shape the production of musical styles and icons of cultural identity in the contemporary world (Feld, 1995). These are strategies of musical geopolitic, of sites production through music, involving a multiplicity of social actors at various levels, local, national and global. The role of popular music in these processes is critical, since it is an immediate tool of production and incorporation of belonging, identity and nation (Adornio, 1971). That is what is happening today with the geopolitical use of Salento's folk music connected to tarantism and its dances).

At the end of the twentieth century, Salento repositioned in the context of the global market of cultural differences. Through its institutions and a strategic link between local government, national state, the European Union, the US market and other supranational institutions (ranging from large multinationals of world music to UNESCO), Salento choose the way of capitalization of intangible assets. It should be noted that, in the bosom 
of the research on patrimonialization of tarantism, loomed from the outset a tension between conservatives and innovators of tradition. However, this ideological conflict did not prevent the organization of events such as La Notte della Taranta (which is held annually in the town of Melpignano since 1998), offset by the Notte di San Rocco in Torrepaduli, with its characteristic dance-fencing (this dance, which belongs to the ethnochoral category of challenge-dance, is performed by two men that move in the center of a traditional 'ronda' (a circle of people in which even musicians take place) mimicking a knife with the fingers of the hand. The gangster character of the dance makes this product difficult to exploit, especially due to the fact that in the actual dynamics of the night of San Rocco this conflict threatens to explode into physical contrasts favored by the ambiguous code of dance-duel (di Lecce, 1992)). Conflict remarked, among other things, by the opposing political camps engaged in the realization of these events.

In relation to what was said therefore emerges a network of central topics for ethnomusicological reflection: from the influence of anthropological studies on local social life to the politics of local cultural and identity production - with their economic, political and social impact on local, national and global plans-; from the idea of preservation of tradition in its authenticity to the speeches related to the contamination of musical genres in contemporary world; from the conflicts that arise for intellectual property of 'traditional' resources to their marketing and distribution in the world. Tarantism, folk music and dancing, knowledge, practices and memories inherited and transformed certainly constitute an extraordinary heritage, a social and cultural capital. But the use of such capital must be tied both to policy and institutional activities, as much if not primarily to active exercise of critical consciousness of citizens. Only by opening a space truly egalitarian of cultural action and spreading the means of expressive production, Salento can be confirmed once again as priority area for exercise not only new means of reflection on cultural heritage, but also new forms of popular participation in democratic life. It would therefore be desirable a reduction of academic ivory towers in favor of an urgent social use - and therefore dialogic - of the new intellectual and scientific awareness.

\section{REFERENCES}

ADORNO T. W. 1971. Introduzione alla sociologia della musica, Einaudi, Torino (ed. or. 1962).

BENJAMIN. W. 1966. L'opera d'arte nell'era della sua riproducibilità tecnica. Arte e società di massa, Einaudi, Torino (ed. or. 1936).

CARPITELLA D. 1961. Appendice III. L'esorcismo coreutico-musicale del tarantismo, in de Martino (1961, pp. 335-72). 
DE GIORGI P. 1999. Tarantismo e rinascita. I riti musicali e coreutici della pizzica pizzica e della tarantella, Argo, Lecce.

DE MARTINO E. 1959. Sud e magia,Feltrinelli, Milano.

ID. 1961. La terra del rimorso. Contributo a una storia deligiosa del Sud, il Saggiatore, Milano.

ID. 1977. La fine del mondo. Contributo all'analisi delle apocalissi cuturali, a cura di C. Gallini, Einaudi, Torino.

ID. 2005. The Land of Remorse: A Study of southern Italian Tarantism, translated and annoteted by D. L. Zinn, foreword by V. Crapanzano, Free Association Books, London.

DE RAHO F. 1994. Il tarantolismo nella superstizione e nella scienza, introduction of G. Lapassade, Sensibili alle foglie, Roma (ed. or. Lecce 1908).

DI LECCE G. 1992. La danza scherma salentina, in "Lares", LVIII.

DI MITRI G. L. 1996. Le radici orfiche e l'innesto paolino sul tronco del tarantismo. Ipotesi e indizi per un'archeologia del sapere, in Studi in onore di Feliciano Argentina, Congedo editore, Galatina.

ID. 2006. Storia biomedica del tarantismo nel XVIII secolo, Olschki, Firenze.

ECOU. 1962. Opera aperta. Formae indeterminazione delle politiche contemporanee.

Bompiani, Milano.

FELD S. 1995. From Schizophonia to Schismogenesis: The Discourses and Practices of World Music and World Beat, in G. E. Marcus, F. R. Myers (eds.), The Traffic in Culture. University of California Press. Berkeley- Los Angeles-London.

FOUCAULT M. 1961. Historie de la folie à l'âge classique, Gallimard, Paris (ed. it. Storia della follia nell'età classica, translated by F. Ferrucci, Rizzoli, Milano 1963).

GIANNATTASIO F. 1991. Tempo e ritmo, in "Grammatica della musica etnica". Bulzoni. Roma.

LAPASSADE G. 1994. Intervista sul tarantismo, with contributes elaborated by C.

Colazzo, E. Imbriani, S. Colazzo, G. L. Di Mitri, M. Blasi, Madona Oriente, Maglie.

LÉVI-STRAUSS C. 1955. Tristes Tropiques, Plon, Paris (ed. it. Tristi Tropici, translated by B. Garufi, il Saggiatore, Milano 1960).

LOMBARDI SATRIANI L. M. 1973. Folklore e profitto. Tecniche di distruzione di una cultura, Guaraldi, Rimini.

PIZZA G. 2004. Tarantism and the politics of tradition in contemporary Salento, in F. Pine, D. Kaneff, H. Haukanes (eds.), Memory, Politics and Religion: The Past Mets the Present in Europe, Max Planck Institute for Social Anthropology, Halle Studies in the Anthropology of Eurasia, Lit Verlag, Münster.

REMOTTI F. 1978. Tendenze autarchiche nell'antropologia culturale italiana, in "Rassegna italiana di sociologia", XIX, 2.

ID. 2015. Il tarantismo oggi. Antropologia, politica, cultura, Carocci editore, Roma. 